\title{
Effective Implementation of Green Computing Using RTI Data
}

\author{
Navdeep Kaur \\ Guru Kashi University, \\ Talwandi Sabo, Punjab, India
}

\author{
Pardeep Mittal \\ Guru Kashi University, \\ Talwandi Sabo, Punjab, India
}

\begin{abstract}
Today in the era of computerization the use of computers has various pros and cons. Computer saves our time and efforts to do a work but it also harmful to our health and environment. Today most of the $\mathrm{CO}_{2}$ emission is caused because of use of computer and its devices. To reduce the harmful impacts of use of computer the concept of green computing must be implemented. Green computing is an approach to use, manufacture and disposed of a computing device with no or minimal impacts on our environment. The concept of green computing would be implemented if both the user and the manufacturer of the computer are taking initiati ves. In this research paper we represent the data collected under RTI Act 2005 from various organizations about their efforts for the implementation of green computing. This data will be useful to represent the awareness of these organizations about green computing and what efforts they are taking for the implementation of green computing. This data is also a part of my research work.
\end{abstract}

Keywords: Energy Star, TCO certification, ICT, eco-friendly, Recyclability.

\section{INTRODUCTION}

Green computing is refers to initiatives to use technology in more environmentally friendly way. The growing green computing movement includes initiative within companies to use power more efficiently, reduce waste, and create more eco-friendly computing products. Many IT manufacturers and vendors are continuously investing in designing every efficient computing device, reducing the use of dangerous materials and encouraging the recyclability of digital devices. The concept Green computing is come into existence in 1992 when the U.S environmental protection agency launched energy star, energy star is voluntary labeling and recognize energy efficiency in monitors, climate control equipment and other technologies. The goal of green computing are power management and energy efficiency choice of eco-friendly hardware and efficient software and material recycling and increasing the product's life. With the help of ICT (Information and Communication Technology), Green computing become an effective approach to grow segments that affects carbon emission. To successful implementation of green computing various organizations and manufacturers have to take initiatives. In this research paper we take a little effort to represent the efforts of some organizations for the implementation of green computing.

\section{OBJECTIVES OF MY STUDY}

The main objectives of my research are:

1. To aware the common man about term green computing.

2. To reduce energy consumption \& protect the environment.

3. To find the difficulties occur in implementation of green computing.

4. To aware the common man about the efforts need to done by them for green computing.

5. To aware the common man about the organizations who take initiatives to promote green computing.
6. To make the people aware about the role of government to promote green computing.

\section{RESEARCH METHODOLOGY}

For implementation of green computing we have to go through various issues and challenges occur in implementation of green computing. After a thorough study of these issues and challenges we choose various factor variables. We found that higher authorities also play a vital role for the implementation of green computing. We use RTI Act 2005 to collect the data from various government institutions about the efforts done for implementation of green computing. We prepare results from their responses.

\section{RTI QUESTIONS}

Q1. Please tell me the total no. of computing devices in your organization?

Q2. Please tell me the count of devices processor category wise (like Intel PIV, i3, i5, i7, celeron, AMD based) in your organization? Please use tabular form if possible.

Q3. Please tell me no. of computing device in your organization with energy star logo?

Q4. Please tell me no. of computing devices in your organization based on operating systems (like Linux, windows, DOS, UNIX etc.)

Q5. Please tell me the no.of conferences/Seminars/workshops conducted by your organization related to green computing for staff or students? Please mention their topics, dates also.

Q6. Please tell me the no. of CRT, LCD, LED monitors currently used by your organization?

Q7. Please tell me how many computing devices are disposed by you in last 5 years (from 1 April, 2009 to 31 March, 2013)? Please use tabular form if possible.

Q8. Please tell me which method of disposing of computing devices was adopted by your organization? 
Q9. Please tell me about your organization's initiatives for green computing in last 5 years (from 1 April, 2009 to 31 March, 2013)?

Q10. Please tell me no. of computing device in your organization with TCO certification?
Q11. Please tell me that is there any campaign done by your organization in last three years to aware about green computing.

\section{RTI DATA}

\begin{tabular}{|c|c|c|c|c|c|}
\hline Q. no. & DICT/CIET NCERT & IIT Ropar & CIET/P\&RD/ NCERT & Punjab InfoTech & CIET/P\&C \\
\hline \multirow[t]{6}{*}{1} & Monitors-97 & 522 & Monitors-29 & Desktop-95 & Monitors-89 \\
\hline & Keyboards-97 & & Keyboards- 29 & Laptop-46 & Keyboards- 89 \\
\hline & Mouse- 97 & & Mouse- 29 & & Mouse-89 \\
\hline & Machine- 97 & & Machine-29 & & Machine-89 \\
\hline & UPS - 97 & & UPS-27 & & UPS-92 \\
\hline & Printers-73 & & Printers-6 & & Printers-67 \\
\hline \multirow[t]{4}{*}{2} & 9 Computers Intel i5 & $\begin{array}{l}\text { All systems of } \\
\mathrm{i} 3, \mathrm{i} 5, \mathrm{i} 7\end{array}$ & N/a & 52 Desktop AMD & N/a \\
\hline & 5 Computers Intel Core & & & $\begin{array}{l}\text { Rest varies from P3 } \\
\text { to i5 }\end{array}$ & \\
\hline & $\begin{array}{l}4 \text { Computers Intel } \\
\text { Pentium D Inside }\end{array}$ & & & & \\
\hline & 7 Computers Intel Core 2 & & & & \\
\hline 3 & Nil & Nil & Nil & $\begin{array}{l}52 \text { Desktop AMD } \\
\text { Energy Star } 5 \text { rest are } \\
\text { old }\end{array}$ & N/a \\
\hline \multirow[t]{3}{*}{4} & 10 Linux & $\begin{array}{l}\text { Linux 90, } \\
\text { Windows } 432\end{array}$ & $\mathrm{~N} / \mathrm{a}$ & $\begin{array}{l}\text { Apple 01, Rest } \\
\text { Windows }\end{array}$ & N/a \\
\hline & 87 Windows 7 & & & & \\
\hline & $\begin{array}{l}\text { All } 97 \text { computer have } \\
\text { DOS, UNIX }\end{array}$ & & & & \\
\hline 5 & Nil & Nil & N/a & NIL & $\mathrm{n} / \mathrm{a}$ \\
\hline 6 & $\begin{array}{l}20 \text { LCD, } 28 \text { CRT, } 15 \\
\text { LED }\end{array}$ & $\begin{array}{l}\text { All LCD and } \\
\text { LED }\end{array}$ & N/a & ALL LCD's & $\mathrm{n} / \mathrm{a}$ \\
\hline 7 & Nil & Nil & N/a & 39 auctioned & $\mathrm{n} / \mathrm{a}$ \\
\hline 8 & Nil & Nil & N/a & open Auction & $\mathrm{n} / \mathrm{a}$ \\
\hline 9 & Nil & Nil & N/a & NA & $\mathrm{n} / \mathrm{a}$ \\
\hline 10 & Nil & Nil & $\mathrm{N} / \mathrm{a}$ & $\begin{array}{l}52 \text { Desktop of } \\
\text { certified as DMI 2.0, } \\
\text { FCC, UL, RoHS } \\
\text { Compliance }\end{array}$ & $\mathrm{n} / \mathrm{a}$ \\
\hline 11 & Nil & Nil & $\mathrm{N} / \mathrm{a}$ & Nil & $\mathrm{n} / \mathrm{a}$ \\
\hline
\end{tabular}

\section{RTI REPORT}

1. DICT/CIET NCERT is using 558 computing devices from which 97 has CPU. Only 9 computers are Intel i5 whereas others are based on Intel Core, Pentium D etc. No computing device has energy star logo. Only 10 computers are based on Linux operating system others are based on Windows. No conferences or seminar is conducted based on Green computing. It use 20 LCDs, 15 LEDs and others are CRT Monitors. In last 5 years no computer is disposed of. It does not take any initiative towards Green Computing in last 5 years. No computer is certified with TCO certification and No campaign is organized in last three years for Green Computing.

2. IIT Ropar is using 522 computers and all the computers are based Intel family 2 processors i.e. i3, i5 and i7. No computing device has energy star logo. 90 computers are based on Linux OS and 432 are based on windows OS. No conferences or seminar is conducted based on Green computing. It use all LCD and LEDs monitors. In last 5 years no computer is disposed of. It does not take any initiative towards Green Computing in last 5 years. No computer is certified with TCO certification and No campaign is organized in last three years for Green Computing. 
3. CIET/P\&RD/NCERT 149 computing devices in which 29 CPUs. No other information is provided by P\&RD department.

4. Punjab InfoTech use 95 Desktops and 46 Laptops. 52 Desktops are based on AMD and others are varies from $\mathrm{p} 3$ to i5. It has 52 desktops with Energy Star. No conferences or seminar is conducted based on Green computing. It use all LCD monitors. In last 5 years 39 computers are disposed of. The method used for disposing is open auction. It does not take any initiative towards Green Computing in last 5 years. 52 computers are certified with TCO certification and No campaign is organized in last three years for Green Computing.

5. CIET/P\&C use 515 computing devices in which 89 are CPUs. No other information is provided by the universities.

\section{CONCLUSION}

The data collected from various organizations it is stated that every organization know about the differences of LCD/LED and CRT monitors but still they are using CRT monitors. Most of the respondent organizations have not using computers with energy star logo. No organization takes any initiative to implement green computing. No seminar and campaign is organized by any organization to promote green computing. No organization is using TCO certified products. The above data states that these organizations have not taking much useful efforts for green computing. They have to take serious efforts for implementation of green computing and to save our environment from the harmful impacts of use of computer and its devices.

\section{REFERENCES:}

[1] Active Energy Manager (AEM): +http://www03.ibm.com/systems/software/director/aem/

[2]Power and Performance trade-off: http://spscicomp.org/wordpress/wpcontent/uploads/2011/05/b rochard-Luigi_Perf-and PowerTrade-off.pdf
[3]
Energy
aware
scheduling:

http://domino.research.ibm.com/library/cyberdig.nsf/papers/ C1C7497C25DBD116852573D400531DFD/\$File/rc24463.pd $\mathrm{f}$

[4]S Ruth. Green IT More Than a Three Percent Solution? IEEE Internet Computing, 2009.

[5]Alexander Szalay, Gordon Bell, H Huang, Andreas Terzis, and Alainna White. Low-power amdahl-balanced blades for data intensive Computing

[6] http://www.wikipedia.org/

[7]http://www.educause.edu/southwest-regionalconference/2010/implementing-green-computing-can-saveyou-some-green

[8] http://www.greencomputing.co.in/

[9] Google green computing report

[10] http://energystar.gov/ 